\title{
Factors Affecting Plant Regeneration from Leaf Tissues of Buddleia Species
}

\author{
Wenhao Dai ${ }^{1,3}$ and Cielo Castillo ${ }^{2}$ \\ Department of Plant Sciences, North Dakota State University, 374C \\ Loftsgard, Fargo, ND 58105
}

Additional index words. Butterfly bush, in vitro, plant growth regulator, photoperiod, organogenesis

\begin{abstract}
The effects of genotype, basal medium, plant growth regulator (PGR), dark treatment, and antibiotics on shoot regeneration of two Buddleia cultivars, $B$. davidii 'Potters Purple' and Buddleia 'Lochinch', were investigated. In vitro shoots were regenerated from leaf tissues in either Murashige and Skoog (MS) or woody plant medium (WPM) media supplemented with benzyladenine (BA). In general, more shoots were regenerated in WPM medium than in MS medium. Dark treatment for 3 to 5 weeks dramatically increased shoot regeneration. Addition of indole-3-butyric acid (IBA) or naphthalene acetic acid (NAA) significantly enhanced the regeneration rate and shoots of each explant. The maximum regeneration rate $(100 \%)$ of $B$. davidii 'Potters Purple' was achieved when cultured in WPM containing $5 \mu$ M BA plus $5 \mu M$ IBA. The maximum regeneration rate $(98.4 \%)$ of $B$ uddleia 'Lochinch' was found in WPM supplemented with $20 \mu \mathrm{M}$ BA plus $4 \mu \mathrm{M}$ IBA. Carbenicillin at 250 to $500 \mathrm{mg} \cdot \mathrm{L}^{-1}$ and cefotaxime at 125 to 250 $\mathbf{m g} \cdot \mathrm{L}^{-1}$, individually or combined, promoted shoot regeneration. Interactions between genotype and medium or PGRs were found. In vitro shoots were easily rooted in halfstrength MS medium with or without NAA. Rooted plants were transferred to potting mix and grown in the greenhouse. This research will facilitate genetic improvement and fast propagation of Buddleia species using biotechnology.
\end{abstract}

The genus Buddleia consists of more than 100 species of which many are woody shrubs providing colorful and fragrant flowers for landscaping and gardening (Dirr, 1998; Hogan, 2003). Native to China, buddleia plants are well adapted to various environmental conditions. Some species are salt-tolerant and others are winter-hardy. Naturally, buddleia plants are seed-propagated. In nursery production, soft wood cutting propagation is the most common method to propagate buddleia species.

Buddleia davidii, known as butterfly bush, is commonly used for landscaping. Butterfly bush was imported to North America from China around the 1900s as a garden shrub. It is a fast-growing deciduous shrub reaching 1 to $5 \mathrm{~m}$ tall and is often lanky and widespreading. Its heavy flowers and long bloom period (from early summer to late fall) are attractive to gardeners. This species is also characterized as winter-hardy (U.S. Department of Agriculture zone 5) and tolerant of a high soil $\mathrm{pH}$ and can be grown in most states

Received for publication 28 May 2007. Accepted for publication 5 July 2007.

This research was supported in part by McIntireStennis Project ND06212 and Landscape Plant Development Center (LPDC).

We thank Drs. E. Deckard, H. Hatterman-Valenti, and J. Zeleznik for their valuable suggestions and comments when we were preparing this manuscript.

${ }^{1}$ Assistant Professor.

${ }^{2}$ Research Specialist.

${ }^{3}$ To whom reprint requests should be addressed; e-mailwenhao.dai@ndsu.edu.
1962) supplemented with $2.67 \mu \mathrm{M}$ benzyladenine (BA), $2 \%$ sucrose, and $0.35 \%$ phytagel (Sigma Chemical Co., St. Louis) and adjusted to $\mathrm{pH} 5.8$ before autoclaving. These cultures were maintained at $25^{\circ} \mathrm{C}$ under coolwhite light at $\approx 36.4 \mu \mathrm{mol} \cdot \mathrm{m}^{-2} \cdot \mathrm{s}^{-1}$ with a $16-\mathrm{h}$ photoperiod.

\section{Plant regeneration}

Experiments were conducted to determine factors affecting plant regeneration of $\mathrm{Bud}$ dleia. Unless otherwise stated, all regeneration media are woody plant medium (WPM) (Lloyd and McCown, 1980) supplemented with MS vitamins, $2.0 \%$ sucrose, and $0.65 \%$ agar (\#0140-01-0; Difco Co., Detroit, MI), and $\mathrm{pH}$ was adjusted to 5.2 before autoclaving. In vitro leaves were cut into two or three segments across the main vein and placed in a petri plate $(100 \mathrm{~mm} \times 15 \mathrm{~mm})$ containing $25 \mathrm{~mL}$ medium. Each treatment had three plates (samples) with 10 leaf segments per plate. In vitro cultures were subcultured in the fresh medium every 4 weeks. Experiments were repeated two or three times.

Effects of basal medium, benzyladenine, and dark treatment on shoot regeneration. Two basal media (MS and WPM) and six concentrations of BA $(0,2.5,5,10,20$, and 40 $\mu \mathrm{M})$ under 0 or 4 weeks dark treatment were evaluated for their effects on shoot regeneration. After being in the dark for 0 or 4 weeks, plates were moved to the 16 -h light/8-h dark photoperiod condition with a light intensity of $36.4 \mu \mathrm{mol} \cdot \mathrm{m}^{-2} \cdot \mathrm{s}^{-1}$. This experiment was conducted as a completely randomized design (CRD) consisting of two replications of a factorial arrangement with a $2 \times 6 \times 2$ of basal medium, BA concentration, and weeks of dark treatment, respectively.

Effects of auxin on shoot regeneration. Two auxins, indole-3-butyric acid (IBA) and naphthalene acetic acid (NAA), at four concentrations $(0,0.5,1$, and $5 \mu \mathrm{M}$ for 'Potters Purple' or $0,2,4$, and $20 \mu \mathrm{m}$ for 'Lochinch') each, were added into the regeneration medium ( $5 \mu \mathrm{M}$ BA WPM medium for 'Potters Purple' and $40 \mu \mathrm{M}$ BA WPM medium for 'Lochinch'). All cultures were maintained in the dark for the first 4 weeks and then moved to the 16-h photoperiod condition for shoot regeneration. The experiment was conducted as a CRD consisting of two replications of a $2 \times 4$ factorial arrangement of cultivar and auxin, respectively.

Effects of antibiotics on shoot regeneration. Carbenicillin $(\mathrm{Cb})$ (Caisson Laboratory, North Logan, UT) at 250 or $500 \mathrm{mg} \cdot \mathrm{L}^{-1}$ and cefotaxime (Cf) (Caisson Laboratory) at 125 or 250 $\mathrm{mg} \cdot \mathrm{L}^{-1}$, individually or combined, was added to the regeneration medium. All cultures were maintained in the dark for 4 weeks and then moved to the $16-\mathrm{h}$ photoperiod condition for shoot regeneration. This experiment was also designed as a CRD consisting of two replications of a $2 \times 7$ factorial arrangement of cultivar and antibiotics, respectively.

The regeneration rate was calculated as the percentage of leaf explants forming shoots after 8 weeks culture (two subcultures) 
for all experiments. The number of shoot regenerated from each leaf explant was counted in Expt. 2 (auxin effect). In other experiments, the shoot number was only estimated.

\section{Rooting and acclimatization}

Regenerated shoots were proliferated in MS medium with $2.67 \mu \mathrm{M}$ BA, $2 \%$ sucrose, and $0.35 \%$ phytagel. In vitro shoots (greater than $1.5 \mathrm{~cm}$ ) were rooted in half-strength MS medium containing $0.65 \%$ agar with four different auxin treatments $(0,0.1,1$, and $10 \mu \mathrm{M}$ NAA) under regular tissue culture conditions (described in "Plant Materials"). Rooting percentage and root number were recorded after 4 weeks of root development. Each treatment had 27 cuttings and was replicated twice. Rooted plants were then transferred to a flat filled with Jiffy Mix (Jiffy Mix, Shippagan, Canada) and covered with a clear plastic top for 1 week. The cover was gradually removed during the next 1-week period. Survival plants were potted into Sunshine Mix \#1 (Fisons Western Corp., Vancouver, Canada) and grown in the greenhouse.

\section{Statistical analysis}

Data from all experiments were subject to analysis of variation and mean comparison using the GLM procedure of SAS software Version 9.1 (SAS Institute, 2004).

\section{Results and Discussion}

Effects of basal medium, benzyladenine, dark treatment, and genotype on shoot regeneration. Basic medium significantly affected shoot regeneration (Table 1). In vitro shoots were regenerated from both cultivars when leaf explants were cultured in either MS or WPM media containing BA (Fig. 1A). However, more shoots were regenerated from leaf explants in WPM medium than in MS medium. Addition of cytokinin (BA) was necessary for shoot regeneration of both cultivars. No shoots were produced and the original leaf explants were dead after 6 to 8 weeks culture if no BA was present in the medium. Significant interaction was found between cultivar and BA concentration. However, interactions between cultivar and other

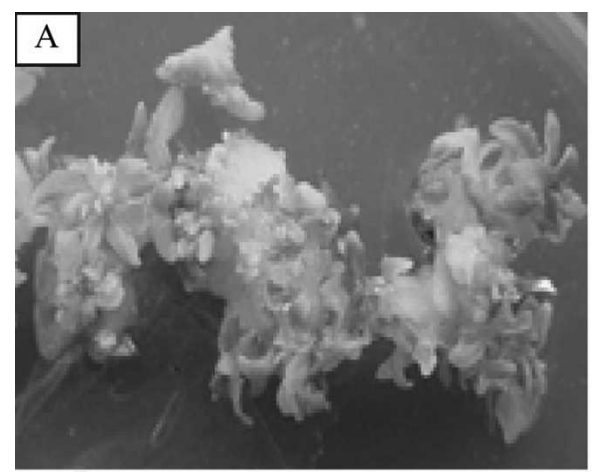

factors such as medium and dark treatment were not significant. Although interactions between dark treatment and BA or cultivar $\times$ BA were significant, no significant interactions were determined between dark treat- ment and other factors. Overall, an average of $20.6 \%$ leaf explants produced shoots in BAcontaining medium after dark treatment for 4 weeks, whereas only $7.1 \%$ of leaf explants regenerated shoots without dark treatment.

Table 1. Effects of basal medium, dark treatment, and benzyladenine (BA) on shoot regeneration of two Buddleia cultivars.

\begin{tabular}{|c|c|c|c|c|}
\hline \multirow[b]{2}{*}{ Photoperiod } & \multirow[b]{2}{*}{ Medium $^{z}$} & \multirow[b]{2}{*}{$\mathrm{BA}(\mu \mathrm{M})$} & \multicolumn{2}{|c|}{ Regeneration rate $^{\mathrm{y}}$} \\
\hline & & & Potter purple & $\overline{\text { Lochinch }}$ \\
\hline \multirow{12}{*}{$\begin{array}{l}\text { weeks dark } \\
\quad(16 / 8 \text { all time) }\end{array}$} & MS & 0 & 0 & 0 \\
\hline & & 2.5 & 11.7 & 5.0 \\
\hline & & 5 & 0 & 15.0 \\
\hline & & 10 & 1.7 & 6.7 \\
\hline & & 20 & 0 & 16.7 \\
\hline & & 40 & 0 & 3.3 \\
\hline & WPM & 0 & 0 & 0 \\
\hline & & 2.5 & 10.0 & 5.0 \\
\hline & & 5 & 15.0 & 10.0 \\
\hline & & 10 & 16.7 & 13.3 \\
\hline & & 20 & 5.0 & 25.0 \\
\hline & & 40 & 0 & 11.7 \\
\hline \multirow{12}{*}{$\begin{array}{l}4 \text { weeks dark } \\
\quad(24 / 0 \text { all time })\end{array}$} & MS & 0 & 0 & 0 \\
\hline & & 2.5 & 31.7 & 10.0 \\
\hline & & 5 & 21.7 & 21.7 \\
\hline & & 10 & 28.3 & 30.0 \\
\hline & & 20 & 11.7 & 16.7 \\
\hline & & 40 & 0 & 36.7 \\
\hline & WPM & 0 & 0 & 0 \\
\hline & & 2.5 & 26.7 & 5.0 \\
\hline & & 5 & 53.3 & 23.4 \\
\hline & & 10 & 33.4 & 43.4 \\
\hline & & 20 & 10.0 & 40.0 \\
\hline & & 40 & 3.4 & 48.4 \\
\hline \multirow{2}{*}{\multicolumn{5}{|c|}{$\begin{array}{l}\text { Least significant } \\
\text { difference }\end{array}$}} \\
\hline & & & 19.96 & 19.96 \\
\hline $\mathrm{SOV}^{\mathrm{x}}$ & & DF & MS & $\mathrm{F}$ \\
\hline Cultivar (Cul) & & 1 & 473.48 & $4.77^{*}$ \\
\hline BA & & 5 & 944.41 & $9.52 * * *$ \\
\hline $\mathrm{Cul} \times \mathrm{BA}$ & & 5 & 808.56 & $8.15 * * *$ \\
\hline Medium (Med) & & 1 & 706.34 & $7.12 *$ \\
\hline $\mathrm{Cul} \times \mathrm{Med}$ & & 1 & 0.45 & $0 \cdot 00 \mathrm{NS}$ \\
\hline $\mathrm{BA} \times \mathrm{Med}$ & & 5 & 128.74 & $1.30 \mathrm{NS}$ \\
\hline $\mathrm{Cul} \times \mathrm{BA} \times \mathrm{Med}$ & & 5 & 178.94 & $1.80 \mathrm{NS}$ \\
\hline Dark (Dar) & & 1 & 4357.82 & $43.95 * * *$ \\
\hline $\mathrm{Cul} \times$ Dar & & 1 & 0.51 & $0.01 \mathrm{NS}$ \\
\hline $\mathrm{BA} \times$ Dar & & 5 & 321.99 & $3.25 *$ \\
\hline $\mathrm{Cul} \times \mathrm{BA} \times \mathrm{Dar}$ & & 5 & 357.62 & $3.61 * *$ \\
\hline Med $\times$ Dar & & 1 & 29.70 & $0.30 \mathrm{NS}$ \\
\hline Cul $\times$ Med $\times$ Dar & & 1 & 29.93 & $0.30 \mathrm{NS}$ \\
\hline $\mathrm{BA} \times \mathrm{Med} \times \mathrm{Dar}$ & & 5 & 31.12 & $0.31 \mathrm{NS}$ \\
\hline $\mathrm{Cul} \times \mathrm{BA} \times \mathrm{Med} \times \mathrm{Dar}$ & & 5 & 36.47 & $0.37 \mathrm{NS}$ \\
\hline
\end{tabular}

${ }^{\mathrm{z}} \mathrm{MS}=$ Murashige and Skoog medium; WPM $=$ woody plant medium.

${ }^{\mathrm{y}}$ The regeneration rate is expressed as the percentage of leaf explants forming shoots after 8 weeks (two subcultures) in vitro culture.

${ }^{\mathrm{x}} \mathrm{SOV}=$ source of variance; $\mathrm{DF}=$ degrees of freedom; $\mathrm{MS}=$ mean square; $\mathrm{F}=\mathrm{F}$ value. ${ }_{\mathrm{Ns}, *, * *, * * * *}$ Nonsignificant or significant at $P \leq 0.05,0.01$, and 0.001 , respectively.
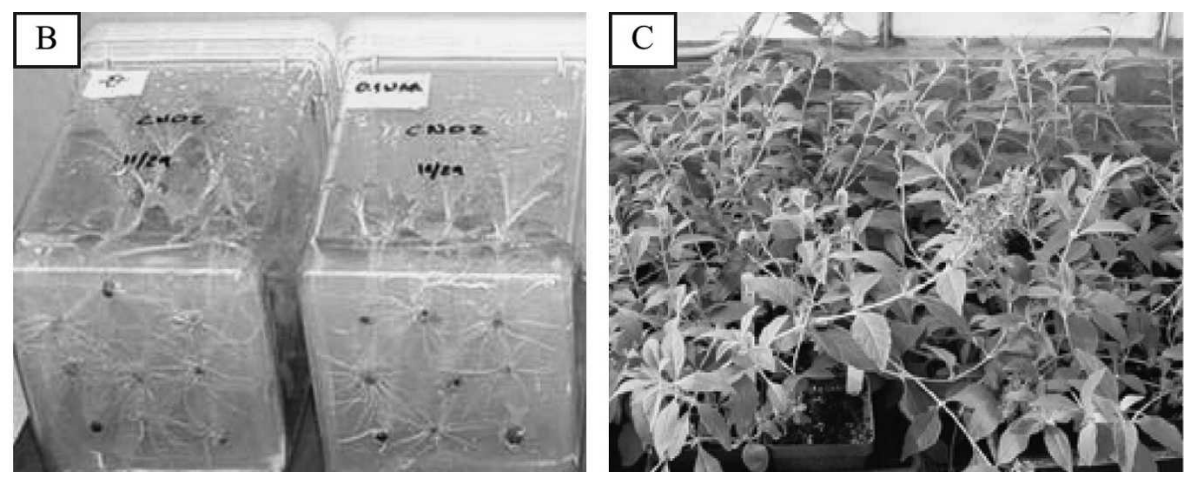

Fig. 1. (A) In vitro shoots were induced from leaf explants in woody plant medium (WPM) containing $5 \mu \mathrm{M}$ benzyladenine and $1 \mu \mathrm{M}$ nmaphthalene acetic acid. (B) Roots were induced from microcuttings in half-strength Murashige and Skoog medium with or without auxin; (C) acclimated plants were potted and grown in the greenhouse. 
In vitro regeneration also showed genotypedependence. With a 4-week dark treatment, an average of $18.6 \%$ and $25.3 \%$ of leaf explants of 'Potters Purple' regenerated shoots in MS and WPM medium, both containing 2.5 to $40 \mu \mathrm{M} \mathrm{BA}$, whereas $23.0 \%$ and $32.0 \%$ of leaf explants of 'Lochinch' produced shoots in the same medium. Maximum regeneration rate for 'Potter Purple' and 'Lochinch' were $53.3 \%$ and $48.4 \%$, respectively, which was obtained from $5 \mu \mathrm{M}$ WPM medium for 'Potters Purple' and $40 \mu \mathrm{M}$ BA medium for 'Lochinch'. It was also found that the bigger the leaf explant, the more the shoots developed within the same species (estimated data, not shown).

The large $F$ value of dark treatment in this study indicated that darkness was one of the most important factors determining shoot regeneration of buddleia species. Limited and controversial information is available regarding the effect of dark treatment on plant regeneration. Although there are reports that dark treatment significantly increased plant regeneration of apple, purslane, persimmon, castors, and so on (Ahn et al., 2007; Choi et al., 2001; Fasolo et al., 1989; Fiore et al., 1997; Gu and Zhang, 2005; RossiHassani and Zryd, 1995), other researches showed no stimulatory effect of dark treatment on plant regeneration of Rubus and Juncus accuminatus (Fiola et al., 1990; Sarma and Rogers, 1998). Our other research results on several species, including aspen, birch, chokecherry, periwinkle, and viburnum, showed that the effect of dark was not only species- but also genotype-dependent (unpublished data). Little is known about why a dark treatment influences in vitro regeneration. It is known that indoleacetic acid (IAA) can be degraded by light. Thus, the inclusion of a dark condition may help keep the optimal ratio of endogenous auxin to cytokinin in in vitro tissues for callus/shoot regeneration. Dark treatment (etiolating plant tissues) may also speed up the process of organogenesis by stimulating dedifferentiation of plant cells (Herman and Hess, 1963). Shortening the photoperiod, decreasing light intensity, and dark treatment will result in thinner cell walls and lower cell wall deposits, facilitating penetration of plant growth regulators into cells (Herman and Hess, 1963).

Although shoots were regenerated in both MS and WPM media, high ammonia and other salts in the MS medium may inhibit shoot initiation. A low ammonium medium has performed better than high ammonium media for Prunus tissue culture (Dai et al., 2004; Perez-Tornero and Burgos, 2000). In addition, higher shoot regeneration rates with the WPM medium in this study indicated that buddleia may be sensitive to high ammonia and other salts during the in vitro regeneration. Thus, determination of medium type should always be one of the first important steps in establishing a regeneration system for different species and genotypes.

Effect of auxin on shoot regeneration. In vitro shoot regeneration of Buddleia was enhanced by the addition of auxin into the regeneration medium (Table 2). Addition of IBA at 0.5 to $10 \mu \mathrm{M}$ or NAA at 0.5 to $1 \mu \mathrm{M}$ and IBA at 2 to $4 \mu \mathrm{M}$ or NAA at $2 \mu \mathrm{M}$ significantly increased regeneration rate for 'Potters Purple' and 'Lochinch', respectively. High concentration of auxin (except IBA for 'Potters Purple'), especially NAA, showed significant inhibition of shoot regeneration. The number of shoots regenerated from each leaf explant was significantly affected by auxin type (Table 2). Significant interactions between cultivar and auxin were found in the regeneration rate rather than shoots per explant, indicating that the number of shoots regen- erated per explant was largely dependent on the genotype and auxin type. An average of 8.7 shoots per responding explant was developed when IBA was added, whereas only 3.5 shoots were produced when NAA was added. More shoots were regenerated from 'Potters Purple' than 'Lochinch'.

In general, the direction of organogenesis of plants in tissue culture is largely determined by the ratio of auxin to cytokinin provided. Endogenous hormones in plants play an important role in balancing the ratio to a certain level for either shoot or root formation. In some species, the ratio of auxin

Table 2. Effects of auxin on shoot regeneration of two Buddleia cultivars. $^{\mathrm{z}}$

\begin{tabular}{llcc}
\hline Cultivar & Auxin $(\mu \mathrm{M})^{\mathrm{y}}$ & Regeneration rate & Shoots per explant \\
\hline Potter purple & Control & 45 & 11.8 \\
& IBA 0.5 & 96.7 & 10.5 \\
& IBA 1 & 95 & 12.7 \\
& IBA 5 & 100 & 12.0 \\
& NAA 0.5 & 91.7 & 7.5 \\
& NAA 1 & 93.4 & 7.7 \\
NAA 5 & 8.3 & 1.0 \\
& Control & 15 & 4.1 \\
& IBA 2 & 81.7 & 7.4 \\
& IBA 4 & 98.35 & 6.7 \\
& IBA 20 & 26.7 & 3.0 \\
NAA 2 & 36.7 & 2.0 \\
Least significant & NAA 4 & 16.7 & 1.2 \\
difference & NAA 20 & 0 & 0 \\
SOV & & & 4.1 \\
Cultivar & DF & 25.1 & MS F \\
Auxin & 1 & MS F & $215.0659 .5^{* * *}$ \\
Cultivar $\times$ auxin & 6 & $9289.2968 .9^{* * *}$ & $41.1611 .4 * * *$ \\
\hline Basic regen & $4148.9930 .7 * * *$ & $7.412 .1 \mathrm{NS}$ \\
\hline
\end{tabular}

${ }^{\mathrm{z} B a s i c}$ regeneration medium: WPM with $5 \mu \mathrm{M}$ BA for Potters Purple and WPM with $20 \mu \mathrm{M}$ BA medium for Lochinch.

${ }^{\mathrm{y}} \mathrm{IBA}=$ indole acetic acid; NAA $=$ naphthalene acetic acid.

${ }^{x}$ The regeneration rate is expressed as the percentage of leaf explants forming shoots after 8 weeks (two subcultures) in vitro culture.

${ }^{\text {w }} \mathrm{SOV}=$ source of variance; $\mathrm{DF}=$ degrees of freedom; $\mathrm{MS}=$ mean square; $\mathrm{F}=\mathrm{F}$ value.

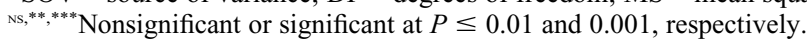

Table 3. Effects of carbenicillin and cefotaxime on shoot regeneration of two Buddleia cultivars. $^{\mathrm{z}}$

\begin{tabular}{|c|c|c|c|}
\hline Cultivar & Antibiotics $^{\mathrm{y}}(\mathrm{mg} / \mathrm{L})$ & \multicolumn{2}{|c|}{ Regeneration rate $^{\mathrm{x}}$} \\
\hline \multirow{7}{*}{ Potter purple } & Control & 76.7 & \\
\hline & $\mathrm{Cb} 250$ & 86.7 & \\
\hline & $\mathrm{Cb} 500$ & 77.8 & \\
\hline & Cf 125 & 76.7 & \\
\hline & Cf 250 & 78.9 & \\
\hline & $\mathrm{Cb} 250+\mathrm{Cf} 125$ & 87.8 & \\
\hline & $\mathrm{Cb} 500+\mathrm{Cf} 250$ & 81.1 & \\
\hline \multirow[t]{7}{*}{ Lochinch } & Control & 52.1 & \\
\hline & $\mathrm{Cb} 250$ & 65.6 & \\
\hline & $\mathrm{Cb} 500$ & 78.9 & \\
\hline & Cf 125 & 50.5 & \\
\hline & Cf 250 & 50.0 & \\
\hline & $\mathrm{Cb} 250+\mathrm{Cf} 125$ & 74.5 & \\
\hline & $\mathrm{Cb} 500+\mathrm{Cf} 250$ & 79.9 & \\
\hline $\begin{array}{l}\text { Least significant } \\
\text { difference }\end{array}$ & & 19.1 & \\
\hline $\mathrm{SOV}^{\mathrm{w}}$ & DF & MS & $\mathrm{F}$ \\
\hline Cultivar (Cul) & 1 & 2786.49 & $21.7 * * *$ \\
\hline Antibiotics (Ant) & 6 & 395.38 & $3.1 *$ \\
\hline $\mathrm{Cul} \times \mathrm{Ant}$ & 6 & 221.73 & $1.7 \mathrm{NS}$ \\
\hline
\end{tabular}

${ }^{\mathrm{z} B a s i c}$ regeneration medium: WPM with $5 \mu \mathrm{M}$ BA for Potters Purple and WPM with $20 \mu \mathrm{M}$ BA medium for Lochinch.

${ }^{\mathrm{y}} \mathrm{Cb}=$ carbenicillin; $\mathrm{Cf}=$ cefotaxime.

${ }^{\mathrm{x}}$ The regeneration rate is expressed as the percentage of leaf explants forming shoots after 8 weeks (two subcultures) in vitro culture.

${ }^{\text {w }} \mathrm{SOV}=$ source of variance; $\mathrm{DF}=$ degrees of freedom; $\mathrm{MS}=$ mean square; $\mathrm{F}=\mathrm{F}$ value.

${ }_{\text {Ns, }}^{*, * * *}$ Nonsignificant or significant at $P \leq 0.05$ and 0.001 , respectively. 
Table 4. Effects of auxin on in vitro rooting of two Buddleia cultivars. ${ }^{\mathrm{z}}$

\begin{tabular}{lccc}
\hline Cultivar & $\begin{array}{c}\text { NAA }^{y} \\
(\mu \mathrm{M})\end{array}$ & \multicolumn{2}{c}{$\begin{array}{c}\text { Rooting } \\
\text { rate }(\%)\end{array}$} \\
\hline Potter purple & 0 & 100 & \\
& 0.1 & 100 & \\
& 1 & 98.2 & \\
Lochinch & 10 & 76.0 & \\
& 0 & 92.6 & \\
& 0.1 & 83.4 & \\
Least significant & 1 & 88.9 & \\
$\quad$ difference & 10 & 92.6 & \\
SOV & & 27.4 & \\
Cultivar (Cul) & DF & MS & F \\
NAA & 1 & 69.31 & $0.5 \mathrm{NS}$ \\
Cul $\times$ NAA & 3 & 105.81 & $0.8 \mathrm{NS}$ \\
Cu & 3 & 208.49 & $1.6 \mathrm{NS}$ \\
\hline
\end{tabular}

${ }^{\mathrm{z}}$ In vitro rooting medium: half-strength Murashige and Skoog medium.

${ }^{\mathrm{y}} \mathrm{NAA}=$ naphthalene acetic acid.

${ }^{\mathrm{x}} \mathrm{SOV}=$ source of variance; $\mathrm{DF}=$ degrees of freedom; $\mathrm{MS}=$ mean square; $\mathrm{F}=\mathrm{F}$ value.

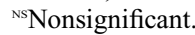

to cytokinin in in vitro tissues needs to be adjusted by providing exogenous cytokinin or auxin to the culture medium. Auxin (NAA and IBA) promotes shoot regeneration for a few plant species such as Dianthus chinensis (Kantia and Kothari, 2002), Rhodiola spp. (Dimitrov et al., 2003; Liu, et al., 2006), and Curcuma amada (Prakash et al., 2004). However, addition of auxin may cause excessive formation of callus tissues, causing somaclonal variation of in vitro shoots.

Effects of carbenicillin and cefotaxime on shoot regeneration. No significant interaction was found between cultivar and antibiotics. Shoot regeneration was increased when $\mathrm{Cb}$ was added into regeneration medium alone or combined with $\mathrm{Cf}$ (Table 3). Addition of $\mathrm{Cf}$ by itself did not affect the regeneration rate. Higher concentration (500 $\mathrm{mg} \cdot \mathrm{L}^{-1}$ ) of $\mathrm{Cb}$ gave rise to more shoots regenerated from each explant (estimated data, not shown).

Carbenicillin and $\mathrm{Cf}$, two most common antibiotics used to eliminate Agrobacterium in plant transformation, have been reported to be effective on callus formation and plant regeneration in several species with a controversial result. Cefotaxime had a stimulatory effect on plant regeneration of Maize (Danilova and Dolgikh, 2004), apple (Yepes and Aldwinckle, 1994), and durum wheat (Borrelli et al., 1992) and inhibitory or no effect on plant regeneration of common snapdragon (Holford and Newbury, 1992), tobacco (Nauerby et al., 1997), and poplar (Ding et al., 2006). Carbenicillin, on the other hand, has shown opposite effects. For example, carbenicillin inhibited regeneration of apple but enhanced callus growth of tobacco and apple (Yepes and Aldwinckle, 1994; Nauerby et al., 1997), indicating that the effect of $\mathrm{Cb}$ and $\mathrm{Cf}$ on in vitro culture is species-dependent. The synergistic effect of $\mathrm{Cb}$ on shoot regeneration of buddleia in this study suggests that $\mathrm{Cb}$ could be broken down to release phenylacetic acid or phenylmalonic acid that have auxin activities in the tissue culture (Holford and Newbury, 1992).

Rooting, acclimatization, and greenhouse performance. In vitro shoots of both cultivars were easy to root in auxin-free medium (Table 4; Fig. 1B). However, application of a low concentration of NAA $(0.1$ to $1.0 \mu \mathrm{M})$ increased the root number (data not shown). In contrast, high NAA $(10 \mu \mathrm{M})$ significantly lowered the rooting percentage of in vitro cuttings. More than $95 \%$ of rooted plants survived after they were potted and grown in the greenhouse (Fig. 1C).

\section{Literature Cited}

Ahn, Y.J., L. Vang, T.A. McKeon, and G.Q. Chen 2007. High-frequency plant regeneration through adventitious shoot formation in castor (Ricinus communis L.). In Vitro Cell. Dev. Biol. Plant 43:9-15.

Borrelli, G.M., N. Di Fonzo, and E. Lupotto. 1992. Effects of cefotaxime on callus culture and plant regeneration in durum wheat. J. Plant Physiol. 140:372-374.

Choi, J.Y., H.J. Kim, C.E. Lee, J.M. Bae, Y.S Chung, J.S. Shin, and N.I. Hyung. 2001. Efficient and simple plant regeneration via organogenesis from leaf segment cultures of persimmon (Diospyros kaki thunb.). In Vitro Cell. Dev. Biol. Plant 37:274-279.

Dai, W., V. Jacques, J. Walla, and Z.M. Cheng. 2004. Plant regeneration of chokecherry (Prunus virginiana $\mathrm{L}$.) from in vitro leaf tissues. J. Environ. Hort. 22:225-228.

Danilova, S.A. and Y.I. Dolgikh. 2004. The stimulatory effect of the antibiotic cefotaxime on plant regeneration in maize tissue culture. Russ. J. Plant Physiol. 51:559-562.

Dimitrov, B., K. Tasheva, N. Zagorska, and L. Evstatieva. 2003. In vitro cultivation of Rhodiola rosea $\mathrm{L}$. Genet. Breed. 32:3-6.

Ding, X., X.Y. Chen, W. Li, and Z.Y. Du. 2006 Effects of antibiotics on plantlet regeneration via organogenesis in Populus euphratica. For. Stud. China. 8:27-31.

Dirr, M.A. 1998. Manual of woody landscape plants. 5th ed. Stipes Publishing, Champaign, IL.

Fasolo, F., R.H. Zimmerman, and I. Fordham. 1989. Adventitious shoot formation on excised leaves of in vitro grown shoots of apple cultivars. Plant Cell Tissue Organ Cult. 16:75-87.

Fiola, J.A., M.A. Hassan, H.J. Swartz, R.H. Bors, and R. McNicols. 1990. Effect of thidiazuron, light fluence rates and kanamycin on in vitro shoot organogenesis from excised Rubus cotyledons and leaves. Plant Cell Tissue Organ Cult. 20:223-228.

Fiore, M.C., T. Trabace, and F. Sunseri. 1997. High frequency of plant regeneration in sunflower from cotyledons via somatic embryogenesis. Plant Cell Rept. 16:295-298.

Gu, X.F. and J.R. Zhang. 2005. An efficient adventitious shoot regeneration system for Zhanhua winter jujube (Zizyphus jujube Mill.) using leaf explants. Plant Cell Rept. 23:775779

Herman, D.E. and C.E. Hess. 1963. The effect of etiolation upon the rooting of cuttings. Proceedings of the International Plant Propagators's Society. 13:42-62.

Hogan, S. 2003. Flora: A gardener's encyclopedia. Timber Press, Inc., Portland, OR.

Holford, P. and H.J. Newbury. 1992. The effects of antibiotics and their breakdown products on the in vitro growth of Antirrhinum majus. Plant Cell Rept. 11:93-96.

Kantia, A. and S.L. Kothari. 2002. High efficiency adventitious shoot bud formation and plant regeneration from leaf explants of Dianthus chinensis L. Sci. Hort. 96:205-212.

Liu, H.J., Y. Xu, Y.J. Liu, and C.Z. Liu. 2006. Plant regeneration from leaf explants of Rhodiola fastigiata. In Vitro Cell. Dev. Biol. Plant 42:345-347.

Lloyd, G. and B. McCown. 1980. Commerciallyfeasible micropropagation of mountain laurel, Kalmia latifolia, by use of shoot-tip culture. Proc. Intl. Plant Prop. Soc. 30:421-427.

Murashige, T. and F. Skoog. 1962. A revised medium for rapid growth and bioassays with tobacco tissue culture. Physiol. Plant. 15:473497.

Nauerby, B., K. Billing, and R. Wyndaele. 1997. Influence of the antibiotic timentin on plant regeneration compared to carbenicillin and cefotaxime in concentrations suitable for elimination of Agrobacterium tumefaciens. Plant Sci. 123:169-177.

Perez-Tornero, O. and L. Burgos. 2000. Different media requirements for micropropagation of apricot cultivars. Plant Cell Tissue Organ Cult. 63:133-141.

Podaras, P. 2005. Breeding a butterfly bush. Landscape Plant News. 16:1, 6-7.

Prakash, S., R. Elangomathavan, S. Seshadri, K. Kathiravan, and S. Ignacimuthu. 2004. Efficient regeneration of Curcuma amada Roxb. plantlets from rhizome and leaf sheath explants. Plant Cell Tissue Organ Cult. 78:159-165.

Rose, J.B., J. Kubba, and K.R. Tobutt. 2000. Induction of tetraploidy in Buddleia globosa. Plant Cell Tissue Organ Cult. 63:121-125.

Rossi-Hassani, B.D. and J.P. Zryd. 1995. In vitro culture and plant regeneration of large flowered purslane. Plant Cell Tissue Organ Cult. 41:281-283.

Sarma, K.S. and S.M.D. Rogers. 1998. Plant regeneration and multiplication of the emergent wetland monocot Juncus accuminatus. Plant Cell Rept. 17:656-660.

SAS Institute. 2004. SAS/STAT 9.1 user's guide. SAS Institute Inc., Cary, NC.

Sheppard, A.W., R.H. Shaw, and R. Sforza. 2006. Top 20 environmental weeds for classical biological control in Europe: A review of opportunities, regulations and other barriers to adoption. Weed Res. 46:93-117.

Tobutt, K.R. 1993. Inheritance of white flower color and congested growth habit in certain Buddleia progenies. Euphytica 67:231-235.

Yepes, L.M. and H.S. Aldwinckle. 1994. Factors that affect leaf regeneration efficiency in apple, and effect of antibiotics in morphogenesis. Plant Cell Tissue Organ Cult. 37:257-269. 